\title{
Megaprojects, Development and Competitiveness: Building the Infrastructure for Globalization and Neoliberalism
}

\author{
By Gerardo del Cerro Santamaria*
}

\begin{abstract}
This paper argues that megaprojects are inherently tied to the logic of growth, development, urban qualitative transformation, wealth creation, competitiveness and prosperity. Megaprojects constitute the infrastructure of globalization and neoliberalism and they actively contribute to a situation of increased planetary urbanization. The causal context of megaprojects - the logic of development and competitiveness - has consequences for the planning and management of megaprojects. In order to meet the goal of contributing to urban and national growth and development, megaprojects are usually shaped as public-private institutional arrangements participated by elites and progrowth coalitions at various spatial scales that are able to provide the necessary funding and expert knowledge to implement these complex structures. The close links between megaprojects, development and competitiveness, and the increasing role of megaprojects in the configuration of megaregions worldwide, have an architectural reflection in the prominent importance of iconicity in megaproject design and construction. Thus, the paper analyzes megaprojects in a dual, interconnected way: as spatial settings and infrastructure units that obey specific planning, design and management priorities, and also as reflections or expressions - as consequences or crystallizations - of larger socioeconomic forces. Megaprojects have multiplied around the world as an urban response to pressures for development, competitiveness and innovation in a context of globalization and neoliberalism.
\end{abstract}

Keywords:iconic megaprojects, megaprojects, megaproject management, megaregions, public/private partnerships.

\section{Introduction}

Megaprojects - urban regeneration schemes, transport and energy infrastructure, industrial corridors, city clusters, new towns, innovation districts, science and technology parks, sports infrastructure - are reconfigured and reterritorialized spaces in which the role of the local, regional, and national elites, as well as the role of national and sometimes transnational capital, is usually prominent. Megaproject design and implementation often meet the need of bringing together and harmonizing several scales of power, not only because increased urban competitiveness and global visibility are perceived as essential outcomes in the development of these projects, but also because, in diverse sociopolitical contexts, the configuration of political power exhibits different and

*U.S. Fulbright Award Recipient (Urban Planning), New York, USA; Member, European Union Expert Committe on Urban and Regional Policy. 
distinct relationships between the local, regional, national, and global domains of social action.

It is important to note that, in a context of planetary urbanization (Brenner and Schmid 2011), virtually all megaprojects are urban in nature and location or are built to have a direct effect on cities and the urbanization process, particularly urban development and competitiveness, because megaproject construction has been a major response to adapt to neoliberalism and globalization in the urban realm, as discussed below. In fact, megaprojects actively contribute to a situation of increased planetary urbanization. Hirschman (1967a: vii, xi) calls megaprojects "privileged particles of the development process" and points out that often they are "trait making," that is, they are designed to ambitiously change the structure of society, as opposed to smaller and more conventional projects that are "trait taking," i.e., they fit into pre-existing structures and do not attempt to modify these.

Urban megaprojects present themselves in many different packages and resist easy definitions, but the close link between megaprojects and development is evident. One could conceptualize UMPs as large-scale urban development projects that sometimes have an iconic design component, that usually aim at transforming or have the potential to transform a city's or parts of a city's image, and are often promoted and perceived by the urban elite as crucial catalysts for growth and even as linkages to the larger world economy. In an era marked by the shift in urban governance from managerialism to entrepreneurialism (Harvey 1989), and one in which cities are thought of as nodes in a global network of relationships, the urban elite often perceive linkages to the global economy as fundamental to ensure sustained local economic development. Regaining global visibility (a concept discussed by Grubbauer 2013) is not only a quintessential economic strategy, it also serves the purpose of symbolic or representational transformation, which is especially useful for regions and cities with distinct political identities. Both objectives - the material and the symbolic - are present in many cities' recent, concerted attempts to regain status as globalizing metropolises through the use of urban megaprojects in urban revitalization (Bunnell 2013). Revitalization itself is a political strategy that questions approaches stressing the exclusively economic and financial character of globalization.

The causal context of megaprojects - the logic of development and competitiveness - has consequences for the planning and management of megaprojects. In order to meet their goals of contributing to urban and national growth and development, megaprojects need to be shaped as public-private institutional arrangements participated by elites and coalitions at various spatial scales that are able to provide the necessary funding and expert knowledge to implement these complex structures. By "development" we understand both the infrastructural development epitomized by megaprojects as well as the neoliberal context of globalization (fostered by developmental states turned entrepreneurial states) within which megaprojects take place and are implemented (Mazzucato 2014, Castells and Himanen 2015).

The paper addresses the planning, design and project management aspects of megaprojects (institutional arrangements and financing at various spatial scales 
and executed locally) as well as the larger causal context of neoliberalism, globalization and competitiveness that explains the rise and development of megaprojects and its linkages with socio-economic development worldwide. The paper is organized as follows. Part One of the paper analyzes the socio-economic causal context of megaprojects. This Part One has three sections: (1) Development and Competitiveness, which looks into the global socio-economic changes due to neoliberalism and globalization that help explain the role of infrastructure and the rise of megaprojects all over the world; (2) Megaprojects and Megaregions, which explores the important role of megaprojects in the rising socio-spatial configuration of the global economy around megaregions and their impacts on development, growth and prosperity; (3) Challenges and Obstacles, which describes some of the socio-economic, institutional and civil society obstacles and problems faced by many megaprojects, due to their highly complex and highly controversial features, in the planning, design and construction phases. Part Two of the paper zooms up to analyzing megaprojects within the planning and management frameworks. Part Two has three sections: (4) Financing and Management, which describes the magnitude of the megaproject phenomenon worldwide, focusing on the rise of private financing and the management of megaprojects for sustainability; (5) Planning and Partnerships, which looks into the public-private institutional arrangements that have been created in most cases to enable and foster the development of megaprojects.; (6) Iconic Megaprojects, which shows how iconicity in design contributes to city visibility on the global map and therefore helps the overall goal of using megaprojects as infrastructure tools to foster development and competitiveness. At the end of the paper, the Conclusions section summarizes the findings presented in the paper.

\section{Part One}

\section{Development and Competitiveness}

In order to understand the links between megaprojects, development and competitiveness we need to briefly discuss the processes of globalization and neoliberalism as causal contexts within which the recent wave of megaprojects came about. Megaprojects have arisen from a complex set of geographic, economic and, above all, political processes of restructuring occurring throughout the world since the late 1970s and early 1980s. This period has seen the widespread ascendency of globalization, neoliberalism, and as an urban manifestation of these processes, the megaprojects, which are inherently tied to a global logic of development and competitiveness.

Globalization and neoliberalism have manifested themselves in four global processes that motivate megaprojects: (1) city-based international competition; (2) the mobility and growth of knowledge economies; (3) the redirection of global investment from physical to human capital; and (4) the dominance of marketrule ideology and politics (Harris 2017). 
Megaprojects are a product of political and economic changes rhetorically framed around a lesser state intervention. However, these projects are "clearly, and almost with no exception, led by the state and often financed by the state" (Moulaert et al. 2003: 551). This degree of state participation symbolizes the tensión between the ideology and the practice of neoliberalism, which is crudely revealed in megaprojects.

A complex reorganization of the relations between the State and the economy is generated under neoliberalism. The State actively enables and promotes marketbased regulatory agreements that favor the private sector (often in the form of "public-private partnerships"), and so urbanization depends on this peculiar and perverted form of mobilization of state power to a greater degree than in previous stages (Brenner and Theodore 2005). In a way, this is a clearly neoliberal version (the "entrepreneurial state") of the formerly called "developmental state", whose paradigmatic example in the world is the Chinese government, controlled by the all-powerful Communist Party of the People's Republic of China.

The Chinese entrepreneurial State began to demonstrate when the teams of the Corps of Engineers of the People's Army started the construction of the Shenzhen Special Economic Zone (SEEZ) once they concluded their work in the reconstruction of Tangshan after the 1976 earthquake. The first skyscraper in the SEEZ, the International Foreign Trade Center, opened its doors in 1985, and it was at the time the tallest building in China. The IFTC was inspired by the Hopewell Center of Gordon $\mathrm{Wu}$ in Hong Kong and rapidly became a widely replicated type of building throughout China. From that skyscraper Deng issued his historic call to the free market in January 1992.

On the other hand, the increases in foreign direct investment (FDI) during the last decades of globalization are an indicator of the impact of the mobility of financial and human capital on urban space. These increases in FDI have occurred in a context of massive economic change, from the centrality of manufacturing industries to the preponderance of the service sector, and particularly information and knowledge, beginning in the second half of the 20th century. This is the central historical turn that has transformed the global geoeconomic landscape. The changes during this period demonstrate the extent of the increase in global mobility of capital. Global FDI in services has continued to grow steadily, while it has declined in primary products and raw materials. Megaprojects developed with the aim of capturing a share of the world's mobile wealth. The narrative of international competitiveness to ensure economic survival is common to most megaprojects (del Cerro Santamaría 2013).

Harris (2017) argues that productivity, quality of life, infrastructure development, cost of living, location of housing, recreational services, to name a few variables, influence the perception of urban prosperity. In addition, Harris argues that the efficiencies of the most populated cities depend, to a large extent, on the degree of accessibility:

"This requires that certain patterns of land use and transportation be coordinated to achieve broad scale benefits. The premises may be, in principle, correct, but it has been shown that the relationship between urban growth and prosperity under urban policies guided by neoliberalism favors certain groups and places while harming 
others, accumulating benefits that are geographically, and in terms of socio-economic status, very unequal " (Harris 2017: 65).

However, here are many variables at play: productivity, quality of life, infrastructure development, cost of living, conveniently located housing, recreation, and services, to name a few. The efficiencies of more populous cities are reliant on a degree of accessibility. This requires certain landuse and transport patterns to be coordinated in order to achieve broad benefits of scale. The premises can be, in principle, correct, but the relationship between city growth and prosperity under urban policies guided by neoliberalism has been shown to favor certain groups and places while disadvantaging others, accruing benefits that are geographically highly uneven.

It is necessary to point out two aspects in the development of megaprojects that are of particular relevance. First, the ideology behind the megaprojects offers the promise of growth, development, competitiveness, wealth generation and prosperity, directly for the protagonists and indirectly for the public; however, there is often no mechanism to guarantee that the benefits will materialize. Second, the similarities in objectives and results in the projects that occur in different geographical, political and social urban contexts are significant: they all show, to varying degrees, a clear model of competitive urban entrepreneurship that seems to be copied from one place to another, overlooking the necessary adjustments to specific contexts (Siemiatycki 2013).

From a typological point of view, the majority of urban megaprojects, particularly the mixed-use ones, can be categorized as a globally active model of urban development. This is enhanced by the fact that this mode of urban development is lucrative for capital markets, which benefit from public financing. Paradoxically, however, public-private partnerships are driven by the desire to reduce public spending (Zimmerman and Eber 2014). Capital markets are an underlying driver of megaprojects, with powerful urban growth coalitions that defend and benefit from their existence and performance.

The rhetoric from megaproject protagonists will always embrace a globalization discourse in which international economic competitiveness is paramount for the prosperity of the city and the state. In both times of genuine bust, or times of obvious boom, this rhetoric dominates public discourse, frames objectives, and guides decision-making processes, despite rarely being operationalized into official project management processes. The structural change that these projects are aiming to bring about, who precisely stands to benefit, and more importantly, what alternatives might be available all remain shrouded in a generic "glossy globalization" discourse that glorifies potential investment and growth while obscuring real urban displacement and sociospatial polarization (Marcuse 1997).

In times of real failure, or times of evident boom, this global rhetoric dominates public discourse, frames objectives and guides decision-making processes, although it is rarely operationalized in official project management processes, which obey other types of priorities. Megaprojects represent a globally embedded approach to city making, development and competitiveness spanning cultural and geographical contexts. It has become the hegemonic approach to 
growth, development, competitiveness, wealth creation and prosperity advocated by urban pro-growth coalitions and elites.

\section{Megaprojects, Megaregions and Competitiveness}

As the urbanization process develops relentlessly around the world and global city-regions become economic units of development and competitiveness in their own right, the role of megaprojects (particularly transport and energy infrastructure, innovation districts, industrial corridors, city clusters, new towns) in providing the infrastructure of development expands.

These megaprojects, and the megaregions where they are built, obey a simultaneous logic of dispersion-concentration of economic activity. The combined action of technology and trade favor the global dispersion of economic activity. In turn, the benefits of mutual proximity of innovation activities and decision-making centers promote economic concentration in large mega-regions, which thus exemplify the extension and intensification of the functional relationships of global cities in large megaregional spaces. Recently, 40 megaregions were identified around the world, representing $18 \%$ of the world's population, two-thirds of the world's economic activity and $86 \%$ of patented innovations (Florida 2007). From this point of view, megaregions are the new urban form of globalization (Harrison and Hoyler 2015).

In the United States there are several differentiated super-regions, defined by economics and demography: the northeast corridor, from Boston to Washington, D.C. (Bos-Wa); Northern California, around San Francisco; Southern California, around Los Angeles; the Great Lakes area, with Chicago as its epicenter; the Arizona Sun Corridor, from Phoenix to Tucson; the Front Range Corridor, from the city of Salt Lake to Denver and Albuquerque (New Mexico); the Cascadia Belt, from Vancouver to Seattle; the Piedmont Atlantic group, from Atlanta, Georgia, to Charlotte, in North Carolina; the Gulf Coast area, between Houston, Texas, and New Orleans; the Texas Triangle area, with Houston, Dallas, Austin and San Antonio; and Florida, which includes Miami, Orlando and Tampa. It is estimated that the aggregate population of these megaregions will reach 277 million people in 2025 , equivalent to $80 \%$ of the projected U.S. population for that year. The gross product of two of these regions (Bos-Wa and Southern California) added is equivalent to one third of the gross product of the United States.

Federal policy can focus on helping these nascent archipelagos thrive and help others to emerge, in places like Minneapolis and Memphis, by collectively forming a grid of metropolitan productive regions efficiently connected through infrastructure megaprojects, better roads, railroads and fiber optic cables. Although the 50 states continue to be the basic organization of the political system, the country is reorganizing itself around regional infrastructure lines and metropolitan clusters that ignore state and even national borders (Khanna 2016). These cityregions are more economically relevant than most American states, and the connectivity, through infrastructure megaprojects, of these urban groups determines the long-term economic viability of Americans to a greater extent than the state in which they live. 
In the coming decades, more than half of the population growth of the United States and almost two-thirds of the economic growth measured in terms of output will take place in the US megaregions. These demographic and economic concentrations will be increasingly connected by their economies, population patterns and land use, infrastructure systems, topography, environmental systems and by a common culture and history. As they consolidate, they will experience great governance and decision-making challenges that can not be resolved at the urban or metropolitan level.

Bruce Katz, of the Brookings Institution, has pointed out that of the 350 major metropolitan areas in the United States, cities with more than three million people have recovered much better from the financial crisis (Katz 2018). Meanwhile, smaller cities, such as Dayton, Ohio, are faltering and have been losing economic power, as have innumerable small disconnected towns across the country. The problem is that while economic reality is on one side, the 50-state model means that federal and state resources are concentrated in a state capital - often a small isolated city - and assigned with little sense of the whole.

The US Congress was once a world leader in regional planning. The Louisiana Purchase, the Pacific Railroad Act (which funded Iowa's railroad expansion to San Francisco with government bonds) and the Interstate Highway and Highway System are examples of the federal government's action on economic development on a continental scale. The Tennessee Valley Authority was an agent for the renewal of post-Depression infrastructure, job creation and industrial modernization across six states. What is needed, in some way, is a return to this way of thinking that is more flexible and with an overall vision.

Efforts are already underway to coordinate metropolitan planning and investment in the United States, as Khanna reports. Quasi-governmental entities such as the Western High Speed Rail Alliance aim to link Phoenix, Denver and Salt Lake City with next-generation trains and the industry. There are groups such as CG/LA Inc. that promote public-private investment in a new national infrastructure project. Regional cooperation and planning is a major issue in the National Association of Governors. But Congress still thinks in terms of states (Khanna 2016). To be sure, the challenge of megaregional governance presents no easy solution, due to the extreme complexity in the demands of changing geographical patterns coupled with the political challenges tied to interregional competitiveness and socio-spatial rescaling.

The Trump administration, and those who follow it, must implement a serious policy of making use of new investments in infrastructure and support the change towards a new urban political economy based on the construction of megaprojects in transport engineering, alternative energy, digital technology and other advanced sectors. In any case, this is not a task only for federal policy, given the geographic size of the country, the decentralized nature of US policy and the multilevel power structures that are required to plan and implement complex projects at the regional level. States must also operate across borders and be able to replace the logic of competition (by attracting activity and employment to the detriment of neighbors) by another logic of coordination, planning and supra-state cooperation. 
One can find transformations towards megaregionalization throughout the world. Despite the millenary history of its cultural and linguistic provinces, China is transcending its traditional internal borders to become an empire of 19 megacity groups with populations of up to 100 million inhabitants each. The three main Chinese megalopolises, centered around the Pearl River delta, the Yangtze River and around Beijing (Jing Jin Ji), stand out for their huge scale (more than double the population of Tokyo, the largest mega region today), its massive development through numerous high-speed rail lines, and its top-down and unopposed planning in an authoritarian political context. Despite the possible fragility of the Chinese model of massive investments in infrastructure (Ansar et al. 2016), these groups of cities, whose borders fluctuate in terms of population and economic growth, will be, over time, the nuclei around which the central government allocates subsidies, designs supply chains and builds connections with the rest of the world (Wu 2017).

The Western countries are following the example. As of 2015, the most important political actors in Italy are no longer their dozens of provinces, but fourteen "metropolitan cities" such as Rome, Turin, Milan and Florence, each of which has merged economically with the municipalities of the surroundings, forming viable subregions in economic terms. This Italian mega-region is the third in importance in Europe and the seventh in the world. Britain is also in the midst of an internal reorganization, with the government leading investments towards a new corridor extending from Leeds to Liverpool known as the "Northern Powerhouse", which can become an additional economic anchor to London and Scotland. Together with the London region, it is the second European mega-region, behind the huge economic and population conglomerate (60 million inhabitants) that includes Amsterdam and Rotterdam, the Ruhr area and Cologne, Brussels and Antwerp and the Lille region, which has an output higher than that of Canada.

The connectivity that underpins the growth of megaregions is not exclusively a matter of building more megaprojects; it is a question not only of infrastructures, but of strategy. It is not just about more roads, railways and telecommunications, manufacturing plants and data centers, but to carefully define where to locate them, in order to maximize public investment without limiting regional or state borders. The megaregional strategies would begin by focusing not on the state lines, but on the existing lines of infrastructure, supply chains and telecommunications, routes that remain remarkably faithful to the borders of the emerging super-regions. In this context, the links between megaprojects and development could not be clearer and more dependent on carefully planned national strategies to promote growth and competitiveness.

On the other hand, the concept of "mega-region" needs to be much more precise, not only to better understand the dynamic relationships among its components, but also to accommodate differences due to the variation of geographical and socio-political contexts. It is necessary to avoid taking the US megaregion model as a globally applicable functional unit without variations, and it is also necessary to include in the analysis richer data sets that provide information on the mobility, connectivity and flow functions of some elements 
(for example, the location of economic activity) that are usually interpreted statically.

In the $21^{\text {st }}$ century, competition for efficient connectivity is likely to drive the evolution of activity and economic processes. To some extent, this competition has already begun with the ambitious Chinese project of the Belt and Road Initiative. The connectivity and strategic connection of cities and regions would allow the United States, China and other countries to win the battle of world trade, investment flows, and supply chains. It is possible that the result of these efforts will determine the rivalry around which country stands as the world's first superpower in the $21^{\text {st }}$ century (Ross and Amekudzi 2009). In this megaregional connectivity strategy, megaprojects will play a fundamental role in maintaining the global competitiveness of nations in the future.

\section{Challenges and Obstacles}

Megaprojects have spread in urban areas around the world and have have frequently caused the displacement of the original inhabitants of these areas and generated strong criticism from civil society. We are heirs to the globalized city, in which it is not possible to conceive anything but the regeneration of areas adjacent to rivers and bays, the recovery of zones previously dedicated to storage and manufacturing, the construction of new transportation infrastructures or the extension of existing ones, as well as the renewal of historical centers. However, the Manhattanization of the world - and the urban political economy that sustains it - also presents difficulties and can create several structural obstacles with direct consequences for the design and implementation of megaprojects in globalizing cities and regions.

A case in point is Dubai, a megaproject set in crisis after the recession that started in 2008. After years in which one could regularly find news about the new architectural marvels of the world constructed in Dubai (including sets of artificial residential islands), the situation has been one of hypertrophy for this onetime urban vision. The bubble burst, and the model of Dubai became yesterday's news. Beginning in September 2008, real estate prices fell, and those who had gotten accustomed to positive news on the emirate were rubbing their eyes in disbelief. The glowing reviews about a permanent acceleration in megaproject construction - when Dubai was considered to be the dynamic and innovative center of the Arabic Peninsula - had turned into disbelief, first, and an admission of defeat not exempt of irony, later. The Emirate was bailed out by Abu-Dhabi, and the economic situation has improved in recent years, but a big weakness for Dubai remains: the city lacks a consistent concept of society, with more than $90 \%$ of its immigrants having very limited rights and unlikely to reside there permanently (Elsheshtawy, 2013).

Situations of economic recession are only one of many obstacles faced by megaproject construction. Another is of a political nature, in particular the lack of strong metropolitan governments provided with the necessary instruments to undertake big projects that can transform the urban image and the urban fabric. Such is the case of Mumbai, which is determined to "Shanghaize" itself, although 
major challenges loom. Unlike in China - where the redistribution of local, regional, and national power has not been a zero-sum game in which the local governments have gained power at the expense of the central government - the deliberate "Shanghaization" of Mumbai has seen the competition between different scales of government result in the concentration of power and resources at the metropolitan level, creating a power gap for the development of urban megaprojects. In China, the redistribution of power has taken place between the different levels, enabling the country to proceed with UMP construction and generally to better adapt to the requirements of the global economy (Ye, 2017).

The organizational obstacles in megaproject development are not minor. Bent Flyvbjerg et al. (2003) already warned of these problems in Megaprojects and Risk with examples of big infrastructure projects in Europe. The development of an urban megaproject is usually completed in various phases, and therefore many rearrangements, corrections, additions, and errors occur, not to mention the usual incapability by developers to limit the final expenses to the initial budget (so-called "cost overruns"). All this produces a lack of transparency that is increasingly difficult to support in view of the increasing activity of civil society, which organizes itself to face the ambitions of the political and economic elites. To cite some examples, megaprojects under construction in Budapest, New York, Paris, and Sao Paulo all illustrate the idea that, in the absence of clear and diaphanous planning - and although the state and the promoters try to explain the genesis and the impacts of the megaprojects - the whole process is perceived as dark and secret. Sometimes, this circumstance is used by the state to violate agreements and contracts of public interest and to reverse previous decisions, as has happened with the National Theater of Budapest, according to Judit Bodnar and Judit Veres (2013).

We cannot forget either, that sometimes UMPs develop in conflict situations - as shown by Alexandra Miller's work on the Afghan Ring Road (2013) - and that organized resistance to megaprojects can be of such a caliber that the state and the promoters fail to carry them out. This happened to Mexico City's proposed international airport project, which has been defeated because of the divisions between and within the political class and citizens initially triggered by the progressive democratization, decentralization, and globalization of the country. Diane E. Davis and Onésimo Flores Dewey (2013) argue that, in the Mexican case, it is also necessary to bear in mind the increasing power of the local state, which favors the civil opposition. The authors also underscore the importance of factors such as cultural identity, historical allegiances, and the geographical location in the mobilization of a wide array of local, national, and international allies against the airport. A lesson of the Mexican case can be that bureaucratic ambiguities and tensions exist with regard to who is responsible for the principal projects of infrastructure in countries that experience a democratic transition. Such ambiguities and tensions can debilitate the proponents of a project and reinforce its opponents. This political and institutional baggage can also prevent urban planning authorities from learning how to respond to past experiences with citizen participation and civil opposition. Thus, the authors argue that the defeat of the airport megaproject in Mexico City was as much a 
reflection of a precarious moment in the political and economic development of the country as it was of the validity and legitimacy of the protests against the project itself.

It is important also to look at the social and socio-cultural context most conducive to the development of UMPs. It seems clear from the evidence we have that it is essential to have widespread social and political support, or perhaps even a degree of acquiescence, for these grand schemes to prosper. Their magnitude and consequent effect on large areas of a city, their enormous economic costs and their massive environmental impacts could create civic mistrust. Nevertheless, movements against UMPs, although not wholly absent, are not as intense as those of decades ago. In many cases, projects are successfully marketed as promoting economic development from which all will benefit. The fact that public funds are diverted from projects that might better benefit a larger number of people is actively obscured. In addition, when relatively few people are indeed affected, it will be difficult to mobilize opposition, a proposition directly questioned in the work on the failed Mexico City airport by Davis and Flores (2013). UMPs sometimes must face internal strife and obstacles that may ultimately modify, delay or immobilize global megaprojects.

\section{Part Two}

\section{Megaproject Financing and Management}

As Bent Flyvbjerg argues, in spite of all of their complexities, challenges and shortcomings,

"megaprojects are not only large and growing constantly larger, they are also being built in ever greater numbers at ever greater value. The McKinsey Global Institute (2013) estimates global infrastructure spending at USD 3.4 trillion per year 20132030 , or approximately four percent of total global gross domestic product, mainly delivered as large-scale projects. The Economist (June 7, 2008) similarly estimated infrastructure spending in emerging economies at USD 2.2 trillion annually for the period 2009-2018" (Flyvbjerg 2014: passim).

Flyvbjerg continues:

"In the five years from 2004 to 2008, China spent more on infrastructure in real terms than in the whole of the $20^{\text {th }}$ century. That is an increase in spending rate of a factor twenty. Similarly, from 2005 to 2008, China built as many kilometers of high-speed rail as Europe did in two decades, and Europe was extraordinarily busy building this type of infrastructure during this period. Not at any time in the history of mankind has infrastructure spending been this high measured as a share of world GDP, according to The Economist, who calls it "the biggest investment boom in history" (Flyvbjerg 2014: 45).

If we include not only infrastructure but also the many other fields where megaprojects are a main delivery model - oil and gas, mining, aerospace, 
defense, ICT, supply chains, mega events, regeneration schemes, transport and energy infrastructure, industrial corridors, city clusters, new towns, innovation districts, science and technology parks, sports infrastructure etc.

"then a conservative estimate for the global megaproject market is USD 6-9 trillion per year, or approximately eight percent of total global gross domestic product. For perspective, consider this is equivalent to spending five to eight times the accumulated US debt to China, every year" (Flyvbjerg 2014: passim).

Some 50 years ago, the American economist Albert Hirschman (1967b) proposed the principle of the hiding hand: projects end up being viable because unexpected events or setbacks that cause cost overruns also spur project managers to be more creative in overcome the adversity, and even increasing benefits The vested interests of coalitions of stakeholders are posited by Bent Flyvbjerg as driving the global boom in megaprojects:

"The subliminal rapture experienced by engineers and technologists from building large and innovative projects is reinforced by the attraction to politicians of large ribbon-cutting events attended by the media, while financiers and trade unions expect to gain in profits and jobs. Aesthetes who appreciate good design and enjoy viewing iconically beautiful structures such as the Bilbao Guggenheim, the Golden Gate Bridge or the Sydney Opera House also influence the funding of ever more monumentally grand projects. While cost overruns are the 'iron law' of megaprojects, Flyvbjerg also postulates a paradox. On the one hand, public and private megaprojects are increasingly in demand, but their management in terms of cost overruns, schedule delays and benefit shortfalls has not improved over the century for which comparable data are available." (Flyvbjerg 2014: passim).

Private finance in megaprojects has been on the rise over the past twenty years. This means that capital funds, pension funds, and banks are increasingly gaining a say in management.

"Private capital is no panacea for the ills in megaproject management, to be sure; in some cases private capital may even make things worse. But private investors place their own funds at risk. Funds and banks can therefore be observed to not automatically accept at face value the cost and revenue forecasts of project managers and promoters. Banks typically bring in their own advisers to do independent forecasts, due diligence, and risk assessments, which is an important step in the right direction" (Flyvbjerg 2014: 61).

Project managers and promoters are getting used to the healthy fact that different stakeholders

"hold different forecasts and that forecasts are not only products of data and mathematical modeling but also of power and negotiation. Why is this more healthy? Because it undermines trust in the misleading forecasts often produced by project promoters" (Flyvbjerg 2014: passim). 
The ideal situation would be one where a method of reference class forecasting (RCF) is used. RCF achieves accuracy in projections by basing them on actual performance in a reference class of comparable actions and thereby bypassing both optimism bias and strategic misrepresentation (Flyvbjerg et al. 2003). According to Flyvbjerg,

"research on how to reform megaproject management is beginning to positively impact practice. Such research has recently made great strides in better understanding what causes the many failures in megaproject delivery, and how to avoid them. For instance, we now understand that optimism bias and strategic misrepresentation are significantly better explanations of megaproject outcomes than previous explanations, including Hirschman's Hiding Hand and Sawyers creative error" (Flyvbjerg 2014: passim).

Managing megaprojects for sustainability is one of the biggest challenges ahead. Sustainability normally refers to environmental practices. In megaprojects, a broader definition, including concepts of economic, social, and institutional sustainability, is appropriate. The San Francisco-Oakland Bay Bridge, which was damaged during the 1989 earthquake and reopened in 2013, was $\$ 5$ billion over budget and took ten years longer than originally projected. But the bridge was built to last for 150 years - much longer than the typical 50 years of serviceand to withstand earthquakes and seismic activity of the highest magnitude. Both factors will support substantial savings down the line. Although determining the bottom line on the Bay Bridge as constructed is difficult, the point is that cost and schedule are not the only ways to judge success. Other factors must be incorporated into the project's cost-benefit analysis. There needs to be a framework to help governments - and the public - understand the larger benefits of a project and to include the impact of economic and social development in the final analysis. That doesn't mean that residents will be less irritated at the daily disruptions of projects that never seem to end. But perhaps, looking at the bigger picture, they will consider them worth the trouble.

The report "Mega-Projects: Lessons for Decision-Makers," by The Omega Centre at the Bartlett School of Planning at University College London, discusses 30 case studies of $\$ 1$ billion-plus mega-projects worldwide. The report shows that most mega-projects were actually close to being on time and on budget. But the team looked well beyond the "iron triangle" of fulfilled schedule, budget, and specifications - and indeed that is the major takeaway from the report. Big projects need to be judged for how they meet objectives over time, amid shifting societal, political, and environmental values. Measuring the success of a megaproject is not linear. There are twists and turns not only in terms of engineering and the emergence of new technology, for example, but in the moving target of public expectations. New problems always crop up that such projects are expected to solve, long after the first blueprints were approved. The long time frame of megaprojects remains problematic, of course. The biggest plans tend get started under political leaders who are almost always gone by the time of completion (Omega Center 2012). 


\section{Planning and Partnerships}

We must note the structures and processes of political-economic coalitionbuilding taking place around UMP development. In Mega-Projects: The Changing Politics of Urban Public Investment by Alan Altshuler and David Luberoff, the authors draw attention to the fact that the role of the federal government in infrastructure provision in the United States has increased significantly since the 1960s and that "in all areas, the megaprojects that survived are the ones for which winning political coalitions could be formed, those that worked when Congress divided the spoils. Cost-effectiveness and consumer sovereignty play essentially no role. In this milieu, what gets built matters less than that something gets built with nonlocal taxpayers' money" (p. 53). The federal role expands in any event, with rearrangements of pro-growth coalitions being developed as needed.

A central aspect to urban megaprojects is the nature of public-private partnerships connecting public officials and private investors as they continue to be the principle vehicles by which the new urban megaprojects are being elaborated and implemented throughout the world. Such type of structures engage in activities that apply private and public resources to carry out specific ambitions that could not be completed by public officials or private developers alone. Mutually beneficial goals motivate pooling resources and risk-sharing, resulting in products that are jointly owned even after the project is completed and operating.

Contemporary public/private partnerships (PPPs) began to be adopted by city officials in the United States in the 1970s for downtown redevelopment projects, setting in motion a policy shift that has since had a profound effect on the practice of planning at home and abroad (Sagalyn 2007). Although its origins can be traced back to the patronage partnerships of the late $19^{\text {th }}$ century in the US (Beauregard and Pierre 2000), its modern roots lie in the previously discussed changes in global relations that transformed urban economics and increased interurban competition and to remedy problems with federal urban renewal efforts (Fainstein 2001). Since the earlier widely publicized flagship projects such as Baltimore's Inner Harbour (Harvey 1989) and Boston's Faneuil Hall Marketplace (Sagalyn and Frieden 1989), public private partnerships increasingly became the vehicle of choice for public agencies looking to engage with the private sector in redeveloping urban sites in American and Western European cities.

Earlier studies by political scientists focused on the imbalances of power within the new joint ventures, and the favorable treatment given to developers to the detriment of communities and other social necessary uses (Logan and Molotch 1987). Commenting on the American and British experiences, and particularly the new waterfront and inner-harbour development in Baltimore, Harvey argued that such public-private partnerships were inherently speculative in execution and design as the risk was to a large extent borne by the public sector. Thus they amounted to little more than a subsidy for affluent consumers and corporations at the expense of local collective consumption for the working poor (Harvey 1989). Such type of criticisms betrayed an ideological aversion to market based solutions and lacked analysis of detailed case studies able to systematically 
assess risk/return or cost/benefit relationships, or whether projects actually performed as their initial financial projections predicted.

Susan Fainstein's detailed study of public/private partnerships in London and New York City in 1980-2000 provides a more balanced analysis of the role of public and private sector in the projects and the usefulness of such structures under certain conditions. Nevertheless, in an overall evaluation, the author tends to side with those arguing that the public-private partnerships were unequal and tended of over-rely on property development as an economic growth strategy while leaving unpursued other strategies that would develop worker skills and directly spur job creation and placement (Fainstein 2001: 218). As an alternative, Fainstein argues that public redevelopment programs and assistance to the private sector can form part of a sensible program, but they need, however, to be within the context of economic planning aimed at creating space to support the industry without glutting the market, including control of price levels and participation in development profits (Fainstein 2001: 220).

Focusing on the redevelopment of Times Square district in New York City during the 80's and 90's, Sagalyn points out that the essence of public/private development is inherent asymmetry in the reduced degrees of freedom that private investors and public officials have to bear in the partnerships. Private developers benefit from greater manoeuvrability because they face few political risks. For city and state officials, however the combined economic and political costs of severing ties are often unpredictably high, so new compromises must be found in revised deals. The political imperative is the bottom line and forces a solution. Thus the challenge is to find forms of engagements that afford some protection for the taxpayer while taking on enough risk as to allow its political goals to be implemented (Sagalyn 2003: 377).

One of the most comprehensive studies done within the European context is Moulaert et al. edited volume of thirteen large-scale urban development projects in twelve European Union countries (Moulaert et al. 2003). The project focused on the way in which globalization and liberalization articulate with the emergence of new forms of governance and on the relationship between large-scale urban development and political, social and economic power relations in the city. Amongst its findings, the authors argue that in contrary to their market-led and entrepreneurial activity and despite their predominantly privatized management structures, urban development projects are decidedly and almost without exception state led and often state financed.

Also, the actual configurations of the project based institutions created to implement the projects reveal an extraordinary degree of selectivity. There is a significant deficit with respect to accountability, representation and presence of formal rules of inclusion or participation. Most importantly, participation is rarely statutory and tends to happen through ad hoc co-optation and invitation, usually by the key power brokers within the institutions. In a general evaluation, the authors decry the lack of democracy and social policy in the new urban development policies and the poor integration of large urban projects in wider urban processes and planning systems (Moulaert et al. 2003: 250). 
In a more recent study, Fainstein argues that public-private partnerships can be a vehicle for the provision of public benefits, including job commitments, cultural facilities and affordable housing. However, such projects are risky for both public and private participants, must be primarily oriented toward profitability, and typically produce a landscape dominated by bulky buildings that do not encourage urbanity (Fainstein 2008: 783). Comparing recent megaprojects in New York, London and Amsterdam, the author concludes that they represent a convergence between American and European approaches to government intervention as embodied in private sector involvement and market orientation.

In The Oxford Handbook of Megaproject Management (2017), Winch states that a 'project stakeholder is any group or individual who can affect or is affected by the achievement of the project misión.' The key conceptual issue that he identifies is the absence of stockholders with a fiduciary claim on the project or organisation, though he ends up only recommending more research on political and social aspects. Ahlers et al. note that dam financiers usually have no obligation to share information with the public. Many megaprojects rely on public-private partnership (PPP) structures, so Hodge and Greve ask what problems are solved by their use, and how well. Because PPPs are effectively mega-credit cards for government, they can address budget constraints by drawing on private finance, although the UK government was forced to rescue projects financed by bank loans during the Global Financial Crisis in 2008. A common rationale for megaproject PPPs is that private sector expertise and discipline can ensure efficiency, timeliness and expenditure accuracy, but Hodge and Greve note that there has been "precious little rigorous and independent empirical work" in the area.

The Sydney Cross City Tunnel and Melbourne's Southern Cross Station are instances of failure due to underestimation of traffic volumes and construction difficulties, respectively. The study of urban megaprojects must be positioned in a context of urban institutional change. In the authors view, processes of decentralization and recentralization in the post-administrative state are producing a continuous rescaling of inter-relationships in the metropolitan arena. Thus, large urban projects can no longer be considered as local projects since their size is embedded in frames of multi-actor and multilevel governance. Such conditions call for new multi-level frames of analysis able to grasp with complex relations between the new projects and the multilayered networks in which they are embedded.

\section{Iconic Megaprojects}

As mentioned earlier, capturing a share of the world's mobile wealth is foundational to the justification of megaprojects. From an urban-spatial and design perspective, this entails that cities need to become "visible" and attractive to international capital. The "icon project" (Sklair 2017), that is, the widespread construction of architectural icons in globalizing cities around the world, accomplishes these goals. The construction of iconic urban megaprojects (IUMPs) has grown into a standard policy choice by urban and regional elites in globalizing 
cities. Politicians, business leaders and others in local and regional growth machines fulfill their personal and professional ambitions by investing in and promoting iconic urban megaprojects, aspiring to reach global status and positive economic change for their cities.

Many urban elites worldwide have been greatly influenced by the so-called "Bilbao effect" - the perception that the Guggenheim Museum Bilbao resulted in a "Cinderella transformation" of the Northern Spanish city and economic capital of the Basque Country. In the dominant discourse concerning architecture's surrender to capitalism's commercial goals, the Guggenheim Bilbao has been and remains to be mistakenly and repeatedly portrayed as the "catalyst" for the city's radically successful transformation from industrial powerhouse to regional service center.

However, many cases around the world suggest (not too surprisingly) that just building a terrific museum is not enough to ensure success. For example, the new Ordos Art Museum in Inner Mongolia, beautifully designed by MAD, a prestigious firm of Beijing architects, has been a failure. The city of Ordos has sprung up fast and is relatively wealthy, thanks to discoveries of oil and gas, but the museum has no collections and precious few plans for exhibitions. No wonder it is devoid of visitors.

As Michael Kimmelman put it:

"The truth is, the Bilbao effect is largely a myth. Frank Gehry's museum alone didn't turn around that city. It capped decades of civic renewal. Flashy, even brilliant buildings rarely rejuvenate neighborhoods or guarantee crowds and cash just by virtue of their design [...] Sadly, museums, like cities, have squandered fortunes praying to this false idol. They still do." (Kimmelman 2012).

As I have shown elsewhere (Del Cerro 2017), the Guggenheim Bilbao has been a positive addition to the city, but far from the "miracle" that would be able to turn Bilbao into a successful urban economy.

The debate on the "Bilbao effect" (how iconic megaprojects can successfully bring about urban transformation, development and competitiveness), however, continues. The Guggenheim in Abu Dhabi, scheduled to open in 2017, but delayed, will be twice the size of the museum in Bilbao, twelve times the size of the Frank Lloyd Wright Guggenheim in New York. Carol Vogel in The New York Times refers to this Gehry design as "a graceful tumble of giant plaster building blocks and translucent blue cones" (Vogel 2014). The outcome of the Guggenheim Helsinki's international competition was known in June 2015, with the winning project going to the Paris-based firm Moreau Kusunoki Architectes (by Fall 2016, the city of Helsinki voted against the project and construction never started).

These two projects have attracted significant criticism; they have been questioned along three main lines: (1) iconic architecture is no longer the hegemonic visual discourse in urban revitalization; (2) the franchise model imposed by the Guggenheim means that local officials have no autonomy to 
make major decisions on matters from exhibition calendars, to budgets and investments; and (3) local cultural identities are usually neglected under a foreign global arts model. In addition, the environmental impacts of the projects may not be negligible. The Abu-Dhabi project has also been controversial around issues of workers's rights and labor conditions. In spite of mounting criticism, if the new Guggenheim Museum in the United Arab Emirates results in even half the impact of that of Bilbao's, the term "Bilbao effect" will continue to carry weight on both sides of the debate.

To be sure, the Bilbao effect faced significant criticism and skepticism among numerous architecture and art connoisseurs. Chicago Tribune critic Blair Kamin noted that the rise of "starchitects" poses a broad set of questions about the impact of globalization on an art that is ultimately local. The critic located the beginning of the trend in the 1976 Houston Pennzoil Place, dubbed by the residents "the milk cartoons." He noted that the fashion spread to other cities such as Chicago in the 1980s, where architects were put in charge to,

\begin{abstract}
"design eye-catching creations that would enhance a building's marketability [...] There is something [...] to be gleaned from starchitects, but only if they are willing to look deeply at [a city] and to adapt their work to the city's essence and its economics" (Kamin 2002).
\end{abstract}

Architectural critic Witold Rybczynski asked whether the cities commissioning new museums by starchitects can become the next Bilbao in terms of visitors. He noted that attendance at the Experience Music Project in Seattle, designed by Frank Gehry for Paul Allen in 1996, decreased by a third eighteen months after the museum opened, while the number of visitors to the local art museum increased by more than a third during the same period. Recently a portion of the building was converted into a science-fiction museum. Despite its unusual architecture, consisting of colorful, rounded forms said to be inspired by electric guitars, the museum of rock music and Jimi Hendrix memorabilia, the Experience Music Project has not proven to be a success. Rybczynski was "skeptical that designing in the full glare of public competitions encourages architects to produce better buildings. The charged atmosphere promotes flamboyance rather than careful thought, and favors the glib and obvious over the subtle and nuanced" (Rybczynski 2002).

More recently, Rybczynski has argued that "perhaps the Bilbao effect should be called the Bilbao anomaly," since "the iconic chemistry between the design of a building, its image and the public turns out to be quite rare, and somewhat mysterious" (2008).

"Herzog \& de Meuron's design for Beijing's Olympic Stadium is ingenious, for example, but instead of the complex engineering, it was the widely perceived image of a 'bird's nest,' a nickname that did not originate with the architects, that cemented the building's international iconic status. The woven steel wrapper seemed to symbolize both China's ancient traditions and its rush to modernization. However, for every bird's nest there are scores of building failures that are not only costly, but fail to spark the public's imagination. Failed icons do not disappear though, which is 
indeed problematic. Since the Bilbao effect mistakenly teaches that unconventional architecture is a prerequisite for iconic status, clients have encouraged their architects to go to greater lengths to design buildings that are unusual, surprising and even shocking. The shock, however, will inevitably wear off, and 100 years from now most aspiring iconic constructions will resemble a cross between a theme park and the Las Vegas strip." (Rybczynski 2008)

Despite the media success of the Bilbao Guggenheim, the Bilbao effect has proven to be difficult to replicate in most places, even for Frank Gehry. On the other hand, some architectural icons, such as Gehry's Stata Center at MIT, work well with no Bilbao effect - most MIT scientists working in the building praise its playful and inventive feel (Campbell 2007). Cooper Union alum Daniel Libeskind's jagged edges, sharp angles and complex geometries (the extension to the Denver Art Museum, the Royal Ontario Museum in Toronto or the Danish Jewish Museum in Copenhagen) have not had the universal acclaim of his Jewish Museum Berlin, an illustration that success, impact and visitor attraction are not necessarily a function of a building's spectacular design. Many works by Shigeru Ban or Tadao Ando are excellent examples of highly admired and successful architecture in the antipodes of iconic buildings designed to stun.

The jury is still out in 2019 regarding not only Gehry's highly anticipated Guggenheim Abu-Dhabi but also the massive West Kowloon Cultural District (WKCD) in Hong Kong, which stand among the most prominent cultural megaprojects in recent years. The WKCD is a project of such scale and ambition that it could "define the nature of the public realm in the $21^{\text {st }}$ century," according to a rather hyperbolic statement by Rem Koolhaas (Koolhaas 2013). The WKCD has met significant criticism from the planning to construction phases. Though a Guggenheim is not part of the project, the WKCD replicates all the expected controversies associated with IUMPs, including cost overruns, negative environmental impacts, gentrification risks, drawbacks of top-down cultural engineering, neglect of local cultural identities, and uncertain economic success. None of these externalities bode well for cities that are counting on instant icons to salvage them during times of economic malaise.

In sum, UMPs often rely on iconic architecture to succeed. Iconic UMPs (IUMPs) have come to play a central role in the standard urban policies designed to gain global visibility and attract visitors and investments to cities. Widely considered a successful case of image reconstruction via iconic architecture, however, the Guggenheim Bilbao, as many other urban icons, presents lights and shadows when the focus of the analysis is on economic and cultural impacts. The Guggenheim Bilbao triggered an immediate and lasting worldwide interest among tourists, artistic circles, the architectural profession, journalists and the educated public, based on the iconic architectural style of the building as well as local, contextual economic and political conditions. Far from being the trigger for, and prime mover of, revitalization, the museum postdated it. Up to now it has not generated substantial foreign investment in the Basque city, nor significant positive outcomes in the job market.

Bilbao's economic performance after the opening of the Guggenheim broadly follows the ups and downs of economic cycles, a clear indication of both the 
embeddedness of cities - and IUMPs - in multiple scales of socio-economic action and the limited power of architectural icons to explain development, competitiveness and urban economic change. In the hypothetical case that the star of the Bilbao Guggenheim begins to dim and visitors cease to arrive in Bilbao in large numbers, the consequences for the Basque city would not amount to significant economic decline, as the museum represents just $2.2 \%$ of the Bilbao economy. Cities are complex formations, and a spectacular building alone, even if projected by experts and the media on a worldwide scale, is not usually capable to shift their fortunes in fundamental ways.

Urban context matters in megaproject planning and implementation. Urban leaders, managers and entrepreneurs in cities worldwide ought to remember that it was not the local government that backed a Guggenheim Foundation in financial trouble, but rather the regional Basque government, with substantial resources of its own and with complete discretion to make decisions about the use of their funds. Furthermore, not every city is well positioned to be "put on the map," especially second or third-tier cities that are comparable to Bilbao in terms of size but are located off main routes and flows of people and commerce. Bilbao is located in one of the top three tourist destinations in the world (Spain), which has been a factor in the museum's spectacular ability to attract visitors. Spain receives about 75 million visitors annually, of which approximately 2.5 million tour the Basque Country, with around one million visiting the Guggenheim Museum in Bilbao.

To be sure, cities should not expect to be able to replicate the success of Bilbao just by implementing fashionable urban policy and appropriate global media discourses. Each city has a local history, a region within which it develops, and a specific political make-up that influences local decision-making processes. Cities and regions around the world partially adhere to their own specific logic of development. Each city shows particular features that contribute to explaining decline, and each may need localized strategies for redevelopment. Applying the standard elements in the revitalization mix, including IUMPs, to cities around the world may be unavoidable due to rapid and acritical adoption of policy discourses from center to periphery. However, expecting to replicate a city's success by merely adopting such strategy often is a recipe for disappointment.

Overall, the place of Bilbao on the world stage has irreversibly changed after the Guggenheim, which unequivocally shows the power of IUMPs to transform a city's image in times of globalization. Moreover, the worldwide media impact of the Guggenheim Bilbao represented a turning point that significantly enhanced the debate about commodification, commercialization and replicability of IUMPs in large-scale redevelopment schemes. As a result, the post-Bilbao dramatic increase in the interest by urban elites to surrender to the promise - and discontents - of IUMPs has become one of the keys to explaining prominent aspects in the deployment of contemporary globalized urbanization. In this context, the traditionally overlooked synergies between research-based evidence, management and governance of IUMPs in globalizing cities ought to become a priority area for urban and regional policy-makers to address (Del Cerro 2017). 
In sum, institutional contexts, specific policy instruments and territorially grounded social dynamics give rise to distinct patterns of IUMP development and help explain the degree to which IUMP succeed or fail. Nevertheless, all initiatives of megaproject planning and construction constitute an urban response to the logic of development, competitiveness, neoliberalism and globalization, as this paper has tried to show. Megaprojects are inherently tied to the logic of growth, development, urban qualitative transformation, wealth creation, competitiveness and prosperity.

These mega-constructions constitute the infrastructure of globalization and neoliberalism and they actively contribute to a situation of increased planetary urbanization. The close links between megaprojects, development and competitiveness, and the increasing role of megaprojects in the configuration of megaregions worldwide, have an architectural reflection in the prominent importance of iconicity in megaproject design and construction. We see that megaprojects invite a dual, interconnected approach: they are spatial settings and infrastructure units that obey specific planning, design and management priorities, and they are also reflections or expressions - consequences or crystallizations - of larger socio-economic forces.

\section{Conclusions}

Megaprojects have multiplied around the world as an urban response to neoliberalism's and globalization's pressures for development, competitiveness and innovation. Megaproject protagonists embrace a narrative of international competitiveness, It is clear, then, that megaprojects are inherently tied to the logic of growth, development, urban qualitative transformation, wealth creation, competitiveness and prosperity. Megaprojects constitute the infrastructure of globalization and neoliberalism and they actively contribute to a situation of increased planetary urbanization. Virtually all megaprojects are urban in nature and location or are built to have a direct effect on cities, city-regions and the urbanization process, particularly urban development and competitiveness. The paper has shown that megaprojects have multiplied around the world as an urban response to pressures for development, competitiveness and innovation in a context of globalization and neoliberalism.

Del Cerro (2013), Flyvbjerg (2014) and Harris (2017) have discussed the main characteristics and criticisms of megaprojects, based on the study of large number of cases around the world in their respective work. The main conclusions of their work are listed here:

1.Urban megaprojects are not just "local" projects designed to enhance particular cities. The visibility and image aim of these projects is often national and international, thus reflecting the ambitions of urban elites. (Del Cerro 2013).

2.Widespread adoption of policy formulas from center to periphery has been crucial for the expansion of the megaproject model of urban growth. The 
limited success of many megaprojects is a consequence of overlooking the importance of contextual forces and patterns when implementing policy. The need to pay attention to context may represent a structural obstacle for the successful development of urban megaprojects in globalizing cities (Del Cerro 2013).

3.In the absence of a clear planning framework, and although both the state and the developer make attempts to clarify the design, planning and implementation of megaprojects, these big developments are still perceived by civil society as filled with secrecy and this contributes to mounting opposition to the development and implementation of UMPs (Del Cerro 2013). One observes "introverted modes of governance that circumvent local planning frameworks, traditional democratic channels of participation, and accountability" (Harris 2017).

4.There is a tension between plans and vision in UMP development, the actual realization of branded megaprojects and the political pressure exerted by the economic and financial interests behind the megaprojects. The positive or negative urban effects of big development plans is significantly dependent on the ability of strategic actors and participants to anticipate or at least adapt to and successfully manage ad hoc problems and side-effects that are frequent in long implementation processes (Del Cerro 2013).

5.Technology and designs are often non-standard, leading to "uniqueness bias" amongst planners and managers, who tend to see their projects as singular, which impedes learning from other projects. Frequently there is overcommitment to a certain project concept at an early stage, resulting in "lock-in" or "capture," leaving alternatives analysis weak or absent, and leading to escalated commitment in later stages (Flyvbjerg 2014).

6.Most megaprojects are physically and socially self-contained, isolated, and disconnected from the context of the host city; they thus promote a similar urban form regardless of the host city that encapsulates a narrow definition of urban life and culture (Harris 2017). The resemblance of most UMPs to conventionalized global city images is suited for some - but clearly not for all - purposes of city marketing. The star-architect paradox is that they aim at creating unique places and yet we witness the multiplication of similar, aesthetically striking cultural facilities and corporation headquarters all over the world with the effect of homogeneizing urban places. Ultimately, there is always the question of how to distinguish the UMP from other projects and of how to make it uniquely identified with the particular city where it is built (Del Cerro 2013).

7.Land use plans can play a role in guiding real estate markets and ensuring an adequate allocation of public resources as an important contributor to the ability of cities to promote growth through urban megaprojects and equitably distribute its costs and benefits (Del Cerro 2013).

8.In most megaprojects, global economic positioning and marketing toward a globally mobile elite prevails over the concern of local issues (Harris 2017). Members of the Transnational Capitalist Class (TCC) and their 
local affiliates can be both particularly innovative in creating enclaves that shield them and their families from the worst effects of UMP and in propagating the culture-ideology of consumerism on which new forms of global urbanity rest. Urban megaprojects and iconic buildings, according to this view, are a powerful tool in transmitting the consumerist values and practices that sustain capitalist globalization (Del Cerro 2013).

9.The local-global logic, or the tensions between place-specificity versus global uniformity, are extremely influential in the design and implementation of UMPs. In this process, contextual elements such as local histories and cultures are important factors to interpret architecture and to adscribe specific meaning (local, regional, national, global) to architectural practices used to build UMPs and make them visible (Del Cerro 2013).

10.In many instances, UMPs are not financially sound projects. They are driven by ostentation and use economics as a mask for completely economically unproductive enterprises built in urban areas that are often ill able to support or withstand them. Due to the large sums of money involved, principal-agent problems and rent-seeking behavior are common, as is optimism bias (Flyvbjerg el al. 2012).

11.Often projects are led by planners and managers without deep domain experience who keep changing throughout the long project cycles that apply to megaprojects, leaving leadership weak. Decision-making, planning, and management are typically multi-actor processes involving multiple stakeholders, public and private, with conflicting interests (Flyvbjerg 2014).

12.Urban megaprojects are usually developed as public-private partnerships with major impacts in the de facto privatization of planning; and they tend to be oriented towards growth and competition rather than socially progressive ends. In general, there is a "minimal commitment to public benefit or socially just policies arising from a primary focus on profitability" (Harris 2017). From this viewpoint, UMPs epitomize the paradigm of the entrepreneurial city and present most of the problems of this urban governance model.

13.Dissent, protest and resistance against urban megaprojects does not happen frequently, but it may be successful when it happens, with the effect of immobilizing the megaproject and defeating the plans of promoters and officials. While the ambitions of urban elites contribute to presenting big projects as indispensable, global networks also help explain why antimegaproject movements might evolve from localized village protests about an unwanted land use into major social movements with transnational linkages (Del Cerro 2013).

14. While the notion of multiple success factors and success criteria is not new to the field of project management and, in fact, constitutes one of the most widely discussed topics in the area, it seems more important than ever. It is therefore becoming increasingly important to assess projects and their impacts at different times and based on different criteria to be able to fully 
evaluate their performance. Success is often driven by political and/or power-related factors. This relates particularly to the topic of how megaprojects are managed. Seeing the highly political nature of stakeholders across the supply chain with different underlying objectives, the hard success factors do not seem to be enough anymore. This unique setup calls for innovative governance solutions that align stakeholder interests in a complex environment with a large number of key players (Harris 2017).

15.There are examples of megaprojects where broader benefits have been achieved, pairing international economic positioning with wealth distribution strategies. These show traces of a Keynesian state model, aiming to counter the cycles and damaging effects of the market, to ensure collective "well-fare" and to reduce inequalities. Two areas offer perhaps the most transferable opportunities, which will be further expanded. They are (1) housing, where significant portions of residential floor space is dedicated to affordable housing; and (2) transport, where the site's rezoned land value is leveraged to finance public transport infrastructure for other parts of the city, as well as for the project itself (Harris 2017).

16. One of the main themes in relation to the future research on megaprojects are the challenges of sustainability and how megaprojects will cope with external industrial influences such as digitization and automation. Sustainability normally refers to environmental practices. In megaprojects, a broader definition, including concepts of economic, social, and institutional sustainability, is appropriate. A megaproject can be defined as sustainable if it is planned and executed to account for the capacity, fitness, resilience, diversity and balance of its urban ecosystem. We take the view of sustainability as an organic process including environment, economy and community: form and efficiency, that is, environmental factors in design, architecture, engineering and construction, as well as policy, i.e., urban plans and practices that explicitly aim at maintaining and improving the social and economic well-being of citizens (Del Cerro 2018).

\section{References}

Ahlers R, Zwarteveen M, Bakker K (2017) Large dam development. from trojan horse to pandora's box. In B Flyvbjerg (ed) The Oxford Handbook of Megaproject Management. London: Oxford University Press.

Altschuler A, Luberoff D (2003) Mega Projects: The Changing Politics of Urban Public Investment. Washington DC: Brookings Institution Press.

Ansar Atif, Bent Flyvbjerg, Alexander Budzier, Daniel Lunn (2016) Does infrastructure investment lead to economic growth or economic fragility? Evidence from China. Oxford Review of Economic Policy 32(3): 360-390.

Beauregard R, Pierre J (2000) Disputing the global: A Sceptical view of locality-based international initiatives. Policy and Politics 28(4): 465-78. 
Bodnar J, Veres J (2013) The petty politics of an urban megaproject in Budapest. In G Del Cerro Santamaría (ed) Urban Megaprojects. A Worldwide View. Bingley, UK: Emerald Group Publishing Limited.

Brenner N, Theodore N (2005) Neoliberalism and the urban condition. City 9(1): 101-107. https://doi.org/10.1080/13604810500092106.

Brenner N, Schmid C (2011) Planetary urbanization. In M Gandy (ed) Urban Constellations. Berlin: Jovis.

Bunnell T (2013) Encountering Kuala Lumpur through the "travel" of UMPs. In G Del Cerro (ed) Urban megaprojects: A worldwide view, 61-82. Bradford, England: Emerald Group Publishing Limited.

Campbell R (2007) Does Gehry's stata center really work? Bloomberg business. Retrieved from https://bloom.bg/2JIXmDT. [Accessed 19 June 2007].

Castells M, Himanen P (2014) Reconceptualizing Development in the Global Information Age. New York: Oxford University Press.

Davis DE, Flores Dewey O (2013) How to defeat an urban megaproject. lessons from the Mexico City airport controversy. In G Del Cerro Santamaría (ed) Urban Megaprojects. A Worldwide View. Bingley: Emerald.

Del Cerro Santamaría G (ed) (2013) Urban megaprojects. A worldwide view. Bingley, UK: Emerald Group Publishing Limited.

Del Cerro Santamaría G (2017) Megaprojects in global context. Revisiting Bilbao. In B Flyvbjerg (ed) The Oxford Handbook of Megaproject Management. London: Oxford University Press.

Del Cerro Santamaría G (2018) Megaprojects, sustainability and competitiveness in the United Arab Emirates. Fulbright Scholar Project Proposal

Elsheshtawy, Y. (2013) Dubai, Behind an Urban Spectacle. London, New York: Routledge.

Fainstein S (2001) The city builders. property development in New York and London, 1980-2000, $2^{\text {nd }}$ edition. Lawrence: University Press of Kansas.

Fainstein S (2008) Mega-projects in New York, London, and Amsterdam. International Journal of Urban and Regional Research 32(4): 768-784.

Florida R (2007) Megaregions. The importance of place. Harvard Business Review, March 2008, citing research by Tim Goulden.

Flyvbjerg B, Bruzelius N, Rothengatter W (2003) Megaprojects and risk: an anatomy of ambition. London: Cambridge University Press.

Flyvbjerg B (2014) What you should know about megaprojects and why. An overview. Project Management Journal 45(2): 6-19. https://doi.org/10.1002/pmj.

Flyvbjerg B, Landman T, Schram S (eds) (2012) Real social science: applied phronesis. Cambridge: Cambridge University Press.

Grubbauer M (2013) "Global" architecture as a contradictory signifier: Lessons from Hamburg's and Vienna's urban megaprojects. In G Del Cerro (ed) Urban Megaprojects: A worldwide view, 185-210. Bradford, England: Emerald Group Publishing Limited.

Harris M (2017) Competitive precinct projects. the five consistent criticisms of "global" mixed-use megaprojects. Project Management Journal 48(6): 76-92.

Harrison J, Hoyler M (eds) (2015) Megaregions: globalization's new urban form? Cheltenham, Glos., U.K.: Edward Elgar.

Harvey D (1989) From managerialism to entrepreneurialism: the transformation in urban governance in late capitalism. Geografiska Annaler: Series B, Human Geography 71(1): 3-17.

Hirschman AO (1967a) Development projects observed. Washington, DC: Brookings Institution. 
Hirschman AO (1967b) The principle of the hiding hand. The Public Interest (Winter): $10-23$.

Hodge G, Greve C (2017) private finance: what problems does it solve, and how well? In B Flyvbjerg (ed) The Oxford Handbook of Megaproject Management. London: Oxford University Press.

Katz B (2018) The New Localism. How cities can thrive in an age of populism. Washington, DC: Brookings Press.

Kamin B (2002) How stellar are "starchitects"? Chicago Tribune, January 27.

Kimmelman, M. (2012, December 23) Why is this museum shaped like a tub? The New York Times, Art and Design Section. https://bit.ly/2VGaD0F.

Khanna P (2016, April 15) A new map for America. New York Times.

Koolhaas R (2013) quoted in E Dunham-Jones, The irrational exuberance of rem koolhaas, Places Journal. https://bit.ly/2VusToN.

Logan J, Molotch H (1987) Urban Fortunes. The Political Economy of Place.

Marcuse P (1997) Glossy globalization. In P Droege (ed) Intelligent environments: Spatial aspects of the information revolution, 29-47. Amsterdam, Netherlands; New York, NY: Elsevier.

Mazzucatto M (2014) The entrepreneurial state. Debunking public vs. private sector myths. New York: Public affairs.

Miller A (2013) The Afghan ring road megaproject. In G Del Cerro Santamaría, (ed) Urban Megapeojects. A Worldwide View. Bingley, UK: Emerald Group Publishing Limited.

Moulaert F, Rodriguez A, Swyngedouw E (2003) The globalized city: economic restructuring and social polarization in European cities. London: Oxford University Press.

OMEGA Center (2012) Mega-projects: lessons for decision-makers. An analysis of selected international large-scale transport infrastructure projects. Bartlett School of Planning, University College London

Ross C, Amekudzi A (2009) Megaregions. Planning for global competitiveness. New York: Island Press.

Rybczynski W (2002) The Bilbao effect. Atlantic Monthly 290(2): 138-42.

Rybczynski W (2008, November 22) when buildings try too hard. Wall Street Journal. https://on.wsj.com/2VuAYtq.

Sagalyn L (2003) Times square roulette. Remaking the city icon. Cambridge, MA: The MIT Press.

Sagalyn L (2007) Public/private development. Lessons from History, research and practice. Journal of the American Planning Association 73(1): 7-22.

Sagalyn L, Frieden B (1989) Downtown Inc. How America rebuilds cities. Cambridge, MA: The MIT Press

Siemiatycki M (2013) Riding the wave: Explaining cycles in urban mega-project development. Journal of Economic Policy Reform 16(2): 160-178. https://doi. org/10.1080/17487870.2013.797904.

Sklair L (2017) The Icon Project. Cities, Architecture and Capitalist Globalization. New York: Oxford University Press.

Vogel C (2014, December 4) A New Art Capital, Finding Its Own Voice. Inside Frank Gehry's Guggenheim Abu Dhabi, The New York Times. Retrieved from https://nyti. $\mathrm{ms} / 1 \mathrm{zA} 8 \mathrm{ttV}$.

Winch, (2017) Megaproject stakeholder management. In B Flyvbjerg (ed) The Oxford Handbook of Megaproject Management. London: Oxford University Press. 
Wu F (2017) China's emergent city-region governance. A new form of state-spatial selectivity through state-orchestrated rescaling. International Journal of Urban and Regional Research 40(6): 1134-1151

Ye, L. (2017) Urbanization and Urban Governance in China: Issues, Challenges and Development, New York: Palgrave Macmillan.

Zimmermann J, Eber W (2014) Consideration of risk in PPP-projects. Business, Management and Education 12(1): 30-46. https://doi.org/10.3846/bme.2014.03. 
